\title{
Advances in Genetics and Breeding of Rice: An Overview
}

\author{
E. A. Siddiq and Lakshminarayana R. Vemireddy
}

\begin{abstract}
Rice (Oryza sativa L.) is life for more than half of the human population on Earth. In the history of rice breeding, two major yield breakthroughs or leaps occurred, which phenomenally revolutionized rice breeding: the Green Revolution in the 1960s and hybrid technology in the 1970s. However, the fruits of these technologies have not spread globally to all rice-growing areas, especially African countries, for diverse reasons. It is estimated that at least $50 \%$ more rice yield is needed to feed the anticipated nine billion people by 2050 . This clearly warrants another breakthrough in rice. It is apparent that the currently used conventional and molecular marker-assisted methods need to be updated with multi-pronged approaches involving innovative cutting-edge technologies for achieving the next breakthrough in rice. Here, we attempt to discuss the exciting avenues for the next advances in rice breeding by exploiting cutting-edge technologies.
\end{abstract}

Keywords Rice · Green revolution · Hybrid rice · Multi-pronged approaches · Gene editing

\section{Introduction}

Rice is the source for more than $20 \%$ of the total calorie intake for more than half of the world population. More than $90 \%$ of it is produced and consumed in Asia. Chronically food-deficit Asia became self-sufficient in this crop by the early 1980s following the introduction and extensive adoption of high-yielding varieties with dwarf plant type starting in the mid-1960s. To sustain this self-sufficiency, it is estimated that the global rice requirement by 2050 will be $70 \%$ more than what is produced now (Fig. 1). Meeting such a huge demand projection sustainably in the face

\footnotetext{
E. A. Siddiq

Institute of Biotechnology, Professor Jayashankar Telangana State Agricultural University, Hyderabad, India

L. R. Vemireddy $(\bowtie)$

Department of Genetics and Plant Breeding, SV Agricultural College, Acharya NG Ranga

Agricultural University (ANGRAU), Tirupati, Andhra Pradesh, India
} 


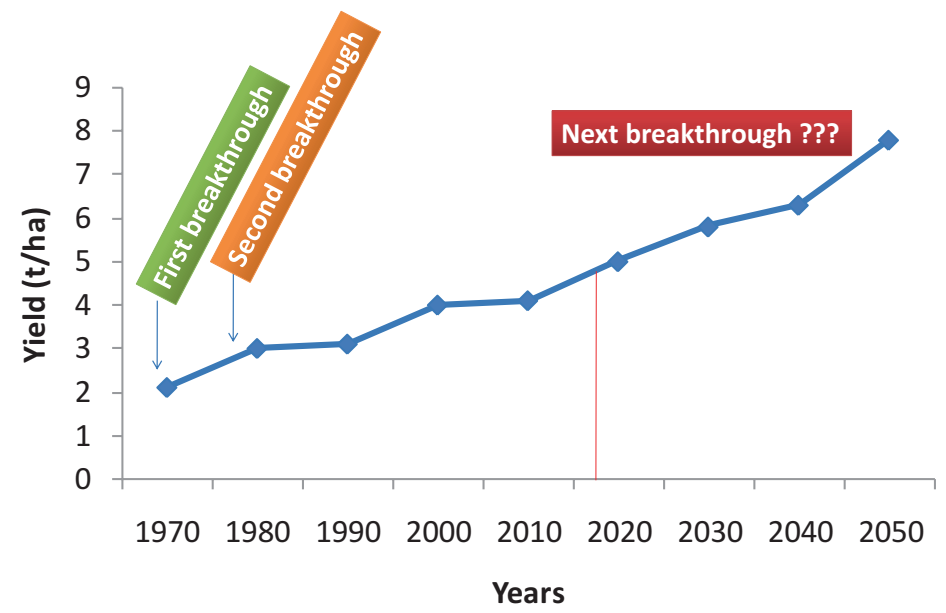

Fig. 1 Rice yield trends and demand projections toward 2050

of the shrinking favorable growth of the 1970s and 1980s, especially for natural resources such as arable land, irrigation water, and genetic resources, is the most challenging task ahead. This situation warrants the discovery of novel gene sources and innovative breeding-selection strategies to develop varieties that would enable the world to meet this challenge.

Systematic breeding for the improvement of Asian rice (Oryza sativa L.), although begun more than a century ago, has been witnessing rapid advances for the past 60 years, with landmark achievements in both applied and mission-oriented basic research. In keeping with the objective of this publication, "Molecular and physiological breeding strategies toward sustained self-sufficiency in rice," this introductory chapter offers an overview of the significant achievements made during this period.

\section{First Breakthrough: The Green Revolution}

Raising the ceiling for genetic yield had been the major breeding objective until the 1950s, when Chinese breeders succeeded with the first-ever dwarf variety, GuangChang-Ai, using the spontaneous dwarf mutant Ai-zi-zhan (Huang 2001), followed by Taichung (Native)-1 in Taiwan using yet another spontaneous dwarf mutant, Dee-Gee-Woo-Gen. Impressed with its yield performance and period-bound maturity, the International Rice Research Institute (IRRI), using the same dwarfing gene source in a cross with tropical japonica variety Peta, developed the miracle yielder, IR8, by the mid-1960s. The extensive adoption of this variety and its derivatives heralded Asia's Green Revolution. Dwarf stature, inherited as a simple recessive trait, together with a set of favorable physiological traits such as increased leaf area 
index (LA1), photo-insensitivity, higher harvest index, and higher fertilizer responsiveness, enabled rice breeders worldwide to develop hundreds of "IR8 plant type" varieties combining the desired maturity range and grain quality. Thus, the DGWG dwarfing gene $(s d l)$ provides short stature in more than $90 \%$ of the high-yielding dwarf varieties being planted globally in the past 50 years. The dwarf varieties developed for the relatively risk-free irrigated ecosystem are not adapted to rainfed upland and lowland ecosystems, which account for more than $45 \%$ of global rice area (Mackill et al. 1996). Efforts to raise the genetic yield of temperate japonica and African rice varieties through the same plant type strategy employing the DGWG dwarfing gene, however, did not succeed except for limited success achieved through variety Tongil in South Korea. Understanding that germplasm of indica origin would not be of help to achieve the plant type goal, the United States and Japan used dwarfing gene sources of spontaneous and induced origin identified in the respective germplasm. Designated as $s d 2$ and $s d 3$, and found to be non-allelic to $s d l$ of DGWG, they have been extensively employed in breeding for higher genetic yield in American and Japanese varieties.

\section{Second Breakthrough: Hybrid Rice Technology}

Ever since the first yield breakthrough achieved through dwarf plant type varieties, keeping in view the need to meet huge future demand projections, especially under limited scope for horizontal growth, breeders have been looking for strategies that would enable them to make a second yield breakthrough. The search took place amid reservations that the chances of finding one such strategy would be difficult as the physiological limit for genetic yield in terms of sink-source equilibrium had already been reached through dwarf varieties. However, this notion was soon proved wrong when Chinese breeders succeeded in the commercial exploitation of hybrid vigor in self-pollinated rice in the late 1970s. Of the more than 20 different cytoplasmic male sterility (CMS) sources, researchers discovered only Wild Abortive (WA), suiting indica rice, and Boro Tai (BT) in japonica rice, which are widely used for commercial hybrid seed production (Li and Yuan 2000; Fuji and Toriyama 2009). More than $90 \%$ of the hybrids cultivated in China are based on WA cytosterility (Sattari et al. 2007). The yield advantage of about $15 \%$ over the best high-yielding dwarf varieties marked the second major yield breakthrough. The adoption of hybrid technology exceeding 18 million ha in a short period of 10-12 years enabled China to add 20 million tons annually to its rice production. Sadly, this proven technology could not be replicated sufficiently in countries outside China. Among the reasons for the slow adoption of the technology, the still unsatisfactory yield advantage, inconsistent yield performance, less acceptable grain quality, and non-suitability of many varieties for the long wet season in countries such as India and Bangladesh are important. Given the recent successes achieved in parental line improvement, some of these deficiencies could be rectified in future hybrids and thereby the pace of adoption of the technology is expected to increase in the coming years. 
With the less attractive yield advantage being one of the major limitations against hybrid rice, various breeding strategies have been attempted across countries to raise yield vigor. Among them, the shift from excessively depending on intrasubspecific combinations (indica/indica or japonica/japonica) to inter-subspecific (indicaltropical japonica or indica/japonica) combinations has been rewarding. The persistent sterility characteristic in indica/japonica hybrids has been overcome following the discovery and use of sterility neutralizing wide compatibility gene (WCG) loci. Using an early discovered WCG such as $S^{n} 5$ obtained from traditional varieties such as Dular, Keta Nanga, and others, many indica-japonica hybrids (Liangyou Pei9, Xieyou 9308, etc.) with yield surpassing that of intra-subspecific hybrids have been developed. Success achieved in overcoming the sterility problem in inter-subspecific hybrids through the use of WCG loci prompted rice geneticists to search for more such genes, leading to the discovery of as many as 50 loci for hybrid fertility. Of these, some were identified in inter-subspecific crosses of $O$. sativa while others were found in crosses between $O$. sativa and other species of the genus Oryza (Ouyang et al. 2009). Among the loci causing female sterility in inter-subspecific hybrids, S5 is a major locus (Song et al. 2005). The locus with three alleles_indica allele $S 5$-i, japonica allele $S 5-\mathrm{j}$, and neutral allele $S 5-\mathrm{n}$ - has been mapped on chromosome 6 (Yanagihara et al. 1995). The tightly linked flanking markers of the S5 gene, RM253 and RM276, have been found quite valuable in developing appropriate parents for producing sterility-free inter-subspecific hybrids (Singh et al. 2006; Siddiq and Singh 2005). Pyramiding of S5-n and f5-n genes was also demonstrated to cumulatively improve percentage seed-setting in indicajaponica hybrids (Mi et al. 2016). Priyadarshi et al. (2017) successfully introgressed a major gene for wide compatibility $\left(S 5^{n}\right)$ into the maintainer line IR58025B through marker-assisted breeding.

Yet another development toward strengthening hybrid rice technology has been hybrid seed production by environment-sensitive genic male sterility (EGMS) using a two-line approach as an alternative to conventional cytoplasmic male sterility using three-line breeding. This was possible following the discovery of photoperiodsensitive male sterility (PGMS) gene sources such as NK58s, PMS1, PMS3, and TMS5, and their non-sensitive gene sources such as Annong IS, Norin12, SA2, and F61 (Siddiq and Ali 1999; Ali 1993; Ali et al. 1995). Dispensing with the need for a male sterility maintainer line, the EGMS system enables the use of a large number of varieties as male parents and thereby increases the probability of identifying more heterotic hybrids. Finding the two-line breeding strategy more efficient and economical in the past three decades, many EGMS system-based two-line hybrids with higher yield, improved grain quality, and resistance to major biotic stresses have been released for commercial planting in China. Now, approximately three million ha are planted to two-line hybrids in China. It is a good sign that interest is growing for the two-line approach in countries such as Vietnam and in multinational seed companies such as RiceTec Inc. Many of the TGMS lines, including SA2 and F61 identified in India, have been linked with robust microsatellite markers enabling the rapid development of inter-subspecific hybrids (Reddy et al. 2000; Hussain et al. 2011). 


\section{Next Breakthrough: Strategies}

After the grand success of the first and second breakthroughs, in the form of semidwarf varieties and hybrid technology, the yield levels of rice have almost reached stagnation. However, the basic understanding of trait inheritance has been enhanced tremendously with the advances in cutting-edge molecular technologies. The next breakthrough requires a multipronged approach involving diverse disciplines and methods (Fig. 2). The following are some of the concepts or pilot studies that have potential to achieve the next breakthrough in rice yield improvement.

\subsection{Enrichment of the Rice Gene Pool}

The most important prerequisite for progressive crop improvement is the availability of genetic variability. Most crop plants are endowed with rich variability and rice is no exception. Wild/weedy species, landraces, modern cultivars, induced mutants, etc. constitute the major source of variability. Despite such rich diversity, more than $80 \%$ of current rice cultivars owe their making to a few parental lines. Strong sexual barriers make it difficult to introgress genes of interest from distant relatives and the possibility of introducing undesirable traits into cultivars via linkage drag dissuaded breeders all along from resorting to the strategy of wide hybridization. As a result, $85-90 \%$ of the variability remains unused in landraces and wild/weedy relatives. Given the rising need for additional/novel variability to meet the unfolding challenges, strategies to bring out the hidden genes in distant rice gene pools and induce variation are inevitable. Whereas association mapping, sequence-based mapping, etc. have been found rewarding in bringing out still undiscovered variability lying in the natural gene pool, induced (CRISPR) and inserted (activation tagging) mutagens could help generate novel variability (Wei et al. 2013).

\subsection{Discovery and Stacking of Yield Genes Hidden in Wild/ Weedy Species}

Wild-weedy gene pools are rich reservoirs of gene sources for breeders looking to progressively improve crop plants and rice is no exception. Aside from finding and using several Mendelian genes largely governing resistance to biotic stresses, the search for genes/QTLs governing polygenically controlled yield and its major components began on the assumption that many of these genes/QTLs might not have been captured in modern varieties during the course of evolution of rice and they could still remain in the wild gene pool (Xiao et al. 1996). If they could be identified by QTL mapping and the harmonious ones stacked in the current high-yielding varieties by marker-assisted breeding, genetic yield could be further increased. This 


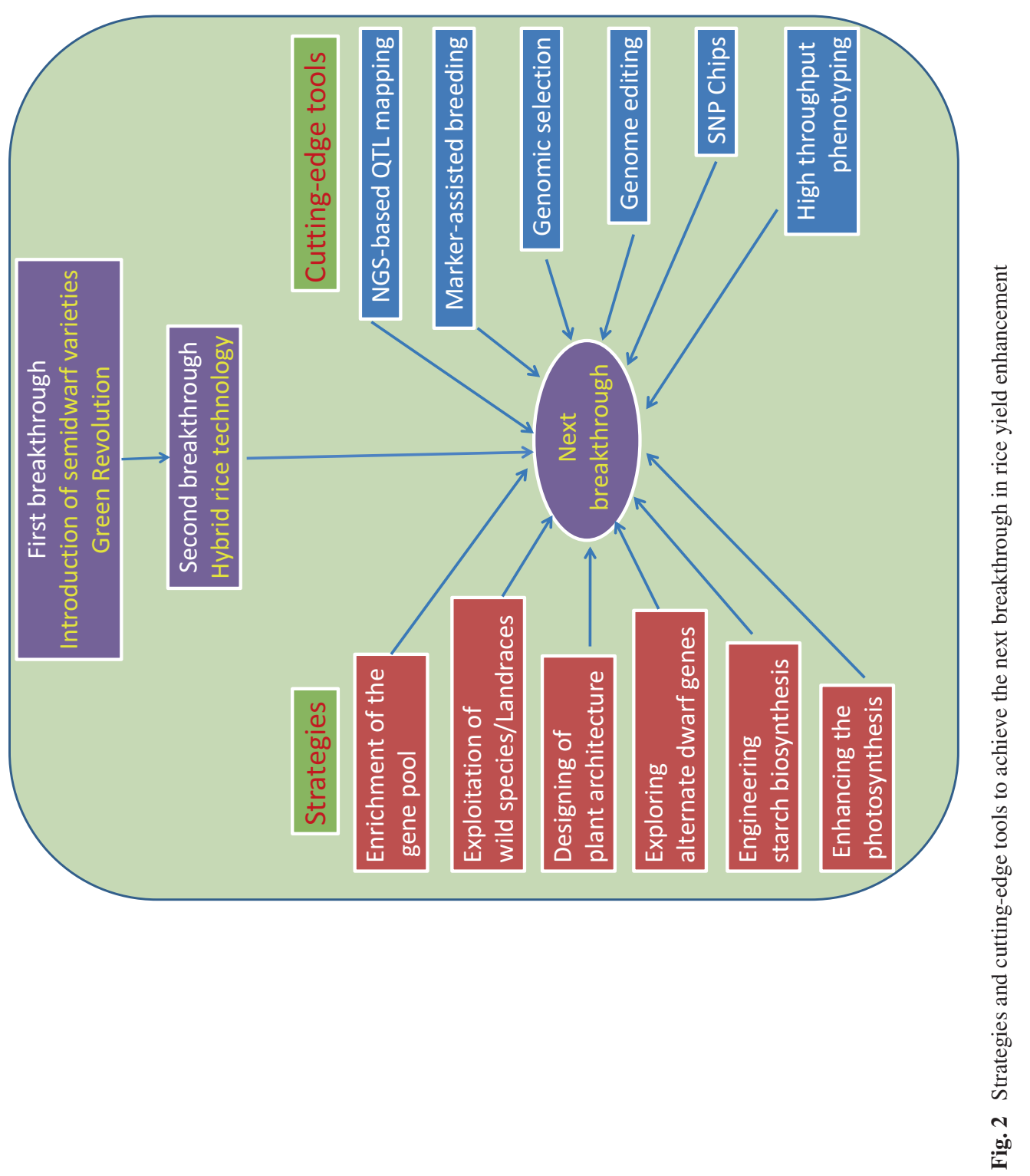


followed the successful mapping and validation of two yield QTLs, yld 1.1 and yld 2.1, in O. rufipogan by the marker-associated QTL approach by Cornell University, USA (Xiao et al. 1996). Worldwide interest was aroused among rice geneticists to search for more and more yield genes/QTLs in wild/weedy relatives and primitive cultivars, resulting in the identification of many promising yield QTLs in O. rufipogan, O. nivara, and landraces (Marri et al. 2005; Kaladhar et al. 2008; Swamy and Sarla 2008; Sudhakar et al. 2012; Swamy et al. 2011, 2012, 2014). This pioneering work culminated in the development of higher-yielding varieties such as Jefferson using yld2.1 from O. rufipogan (Imai et al. 2013), DRR Dhan 40 involving yield genes/QTLs derived from O. nivara (Haritha et al. 2017), and the high-yielding salinity-tolerant IET21943 based on a yield QTL from O. rufipogon (Ganeshan et al. 2016) (Table 1).

\subsection{Designing of Plant Architecture or Ideotype Breeding}

On the strength of findings from simulation modeling, IRRI physiologists believed that the potential yield of $10 \mathrm{t} / \mathrm{ha}$ achieved through dwarf varieties could be further increased by 25\% (Dingkuhn et al. 1991) through enhancement of biomass/unit area without altering the harvest index $(\approx 45 \%)$. This prompted IRRI breeders to conceptualize and tailor a morpho-physiologically more efficient new plant type (NPT) suited to high-density planting. Characterized by less profuse tillering habit, long and upright top leaves, heavy panicles, and robust and active root system, the

Table 1 List of wild species/landraces used for trait enhancement in rice

\begin{tabular}{|c|c|c|c|}
\hline Donor species & Recipient species & Trait transferred & Reference \\
\hline Oryza rufipogon & Oryza sativa & Yield & Xiao et al. (1996) \\
\hline O. glumaepetula & O. sativa & Yield & Brondani et al. (2002) \\
\hline O. grandiglumis & O. sativa & Yield & Ahn et al. (2003) \\
\hline O. rufipogon & O. sativa & Yield & Liang et al. (2004) \\
\hline Landrace (FR13A) & O. sativa (Swarna) & Submergence tolerance & Xu et al. (2006) \\
\hline $\begin{array}{l}\text { O. nivara } \\
\text { (IRGC81848) }\end{array}$ & O. sativa (Swarna) & $\begin{array}{l}\text { Yield and contributing } \\
\text { traits }\end{array}$ & $\begin{array}{l}\text { Swamy and Sarla } \\
(2008)\end{array}$ \\
\hline $\begin{array}{l}\text { O. nivara (KDML } \\
105)\end{array}$ & $\begin{array}{l}\text { O. sativa } \\
\text { (Rathuheenathi) }\end{array}$ & BPH resistance $(B p h 3)$ & Jairin et al. (2010) \\
\hline $\begin{array}{l}\text { Landrace (Basmati } \\
\text { 370) }\end{array}$ & $\begin{array}{l}\text { O. sativa } \\
\text { (Manawthukha) }\end{array}$ & $\begin{array}{l}\text { Fragrance and amylase } \\
\text { content }\end{array}$ & Yi et al. (2009) \\
\hline $\begin{array}{l}\text { O. rufipogon (IRGC } \\
\text { 104814) }\end{array}$ & $\begin{array}{l}\text { O. sativa } \\
\text { (Koshihikari) }\end{array}$ & Blast resistance & $\begin{array}{l}\text { Hirabayashi and Sato } \\
(2010)\end{array}$ \\
\hline Landrace (FL 478) & O. sativa (AS 996) & Salt tolerance & Luu et al. (2012) \\
\hline O. rufipogon (Coll-4) & O. sativa (B 29-6) & Blast resistance $(\mathrm{Pi})$ & $\begin{array}{l}\text { Ram and Majumder } \\
(2007)\end{array}$ \\
\hline Landrace (Tetep) & O. sativa (PRR78) & Blast resistance $(P i 54)$ & Singh et al. (2012) \\
\hline O. meridionalis & O. sativa & Blast resistance $(P i-c d)$ & Fujino et al. (2019) \\
\hline
\end{tabular}


NPT lines developed at IRRI have been reported to yield 11-12 t/ha vis-à-vis 13-14 t/ha reportedly achieved by Chinese breeders in indicaltropical japonica hybrids in the further improved NPT background (Yuan and Fu 1995).

\subsection{Designing of Shoot and Panicle Architecture}

Evidence suggests that, by altering shoot and panicle architecture, genetic yield can be substantially increased. Shoot architecture includes traits that affect plant height and leaf length, width, and thickness, whereas panicle architecture involves traits that affect panicle number, panicle length, number of grains per panicle, and grain weight. With precise information available on the mapping positions of QTLs and access to many cloned genes for the key traits, it is now possible to design the architecture of the rice plant by pyramiding appropriate QTLs/genes. The genes that control grain number (Gnla, Ghd7, DEPl, and WFP), grain weight (GS3 and $G W 2$ ), grain filling $(G I F 1)$, grain size $(G S 3$ and $G W 5)$, and panicle number (DEP1 and $W F P$ ) are fortunately located on different chromosomes, which would enable combining favorable genes/QTLs easily into elite varietal backgrounds.

Earlier, many researchers showed that pyramiding of multiple yield-related genes enhanced yield significantly. Ashikari et al. (2005) were successful in increasing grain number by $45 \%$ and decreasing plant height by $20 \%$ by combining the grain number QTL $(G n l a)$ and the semi-dwarfing gene $(s d l)$ by a pyramiding strategy. Later, Ando et al. (2008) reported that a pyramided near-isogenic line (NIL) containing two QTLs ( $q S B N 1$ for secondary branch number on chromosome 1 and $q P B N 6$ for primary branch number on chromosome 6) developed by introgressing a QTL from Habataki (indica) into Sasanishiki (japonica) produced more spikelets than the independent NIL harboring the QTLs $q S B N 1$ and $q P B N 6$. Further, this pyramided line $(q S B N 1+q P B N 6)$ showed 4-12\% higher yield than the recurrent parent Sasanishiki because of greater translocation of carbohydrates from stem to panicle (Ohsumi et al. 2011). Wang et al. (2012a, b) also demonstrated that the pyramid line $(q H D 8+G S 3)$ had higher yield potential, longer grains, and more suitable heading date than the recipient parent, Zhenshan97.

In addition to gene pyramiding with the aid of marker technology, some successful attempts have been made to increase yield through genetic engineering of plant architecture traits. One such effort employed light-regulated overexpression of the Arabidopsis phytochrome A gene by Cornell University (Garg et al. 2006). Phytochromes are a family of red/far red light-absorbing photoreceptors, which control plant development and plant metabolic activities. The group demonstrated that, by splicing the Arabidopsis PHY A gene into rice by employing light-regulated tissue-specific $r b c$ promoter, plant stature could be altered by further decreasing the height of the already semi-dwarf variety and simultaneously increasing the number of productive tillers, resulting in significantly higher yield than for the control variety. In another study, Wang et al. (2015) reported that transgenic rice plants expressing the Arabidopsis phloem-specific sucrose transporter (AtSUC2), which loads 
sucrose into the phloem under control of phloem protein 2 promoter ( $\mathrm{pPP} 2)$, showed $16 \%$ higher grain yield than the wild type in field trials. Park et al. (2017) demonstrated overexpression of the gene $O s G S$ to improve redox homeostasis by enhancing the glutathione pool, which resulted in greater tolerance of environmental stresses in addition to higher grain yield and total biomass.

\subsection{Modification of Root Architecture}

Genetic improvement of the root system is important for developing tailor-made varieties tolerant of abiotic stresses. A deeper, thicker, and more branched root system with high root to shoot ratio is usually preferred for plants to withstand drought stress. Although drought tolerance has been extensively investigated for the past few decades, an in-depth study to understand its genetics and breeding behavior has hardly been attempted because of its complex nature and the tedious work involved in phenotyping of the root system. However, it is known that rice germplasm is rich in variability for root traits and that the root system and related traits are governed by many genes with small effects, often regarded as QTLs. Now, more than 600 QTLs have been identified for various root-related traits (www.gramene.org). Of the 162 functionally characterized root-related genes, most are annotated as being related to transport and transcriptional or hormonal regulation. The vast majority $(98 \%)$ of these genes have been identified through reverse-genetic approaches and, of these, only three (PSTOL1, DRO1, and Bet1) identified based on natural allelic variation affecting phenotype. Despite such a large number of QTLs available, only two related to nutrient uptake, PSTOL1 at the Pupl locus (Chin et al. 2010) and the root length QTL $q R L 6.1$ that governs nitrate uptake from deeper soil layers (Obara et al. 2010), have been used.

The recent development of several non-invasive 2D and 3D root imaging systems has enhanced our ability to accurately observe and quantify architectural traits in complex whole-root systems. Coupled with the powerful marker-based genotyping and sequencing platforms currently available, root phenotyping technologies lend themselves to large-scale genome-wide association studies, and can speed up the identification and characterization of the genes and pathways involved in root system development.

\subsection{Green Super Rice for Sustainable Performance}

As a massive breeding effort placing emphasis on developing ecologically and economically sustainable varieties in high-yield backgrounds for resource-poor rice farmers in Asia and Africa, the Green Super Rice (GSR) Project was launched jointly by the Bill \& Melinda Gates Foundation, Chinese Academy of Agricultural Sciences, and IRRI. The breeding strategy consists of developing advanced 
backcross populations involving selected popular high-yielding varieties (40-50) chosen from major rice-growing countries as recurrent parents and around 500 varieties with traits of unique adaptive value as donors. Advanced backcross generations $\left(\mathrm{BC}_{2} \mathrm{~F}_{2}\right)$ are then screened under targeted stress conditions for transgressive segregants exceeding the respective parents and local checks in their trait performance. This is followed by pyramiding of complex trait-specific non-allelic QTLs of promise derived from different donor sources into country-specific popular varieties such as IR64, BR11, BG300, and Huang-Hua-Zhan. The recovery of promising lines in large numbers is attributed to the harmonious complementation of genetic networks for complex traits, which otherwise are incomplete in both parents (Ali et al. 2012). While the breeding emphasis of the GSR strategy is for developing eco-friendly/farmer-friendly varieties/hybrids, the massive exercise is bound to produce as well super-yielding varieties/hybrids.

\subsection{Physiological Breeding Approaches}

Exploring Alternative Sources of Dwarfing Genes Given the experience with maize (corn) in the United States, that genetic uniformity for even one gene would make any crop plant vulnerable to a sudden outbreak of any pest, rice breeders have been apprehensive of such an eventuality due to the widespread and excessive use of the dwarfing gene $s d l$ in rice breeding, thus warranting diversification of the dwarfing gene. In rice, as many as 192 dwarfing genes are known. They include both dominant/semi-dominant and recessive inheritance: D53, Ssil, Sdd(t), Dx, TID1, LB4D, Slr-f, D-h, dl3, Sdt97, etc. (http://shigen.nig.ac.jp/rice/oryzabase). Dwarf mutants characterized at the molecular level have been found for their short stature as a result of defective signal transduction molecules such as heterotrimericG protein (Ueguchi-Tanaka et al. 2000), homeobox-like OSH15 (Sato et al. 1999), brassinosteroids (Yamamuro et al. 2000), and various GA biosynthesis genes (Sasaki et al. 2002; Itoh et al. 2004).

The $s d l$ gene-based modern semi-dwarf varieties, aside from being short in stature, are associated with some pleiotropic effect on other traits that reportedly include decreased spikelet number and grain weight (Murai et al. 2002), decreased root length (Lafitte et al. 2007), and poor response to applied nutrients (Zhang et al. 2013). Yet other research underway is looking for a novel allele of $s d l$ that would be devoid of such negative effects on yield components and thereby help develop a dwarf plant type variety with still higher potential yield. Differing from the traditional tall-statured native varieties, wherein the GA pathway remains intact vis-à-vis the modern semidwarf varieties, wherein the GA pathway has been suppressed (GA-repressed), an allele of $s d l$ or some other height-reducing genetic mechanism that would affect the GA pathway (GA-independent) might help to find a new yield threshold. A novel and valuable dwarfing gene, asd-1 (alternate semi-dwarf gene), was identified on chromosome 1 employing a QTL-seq approach (Gopalakrishna et al. 2017). 
Engineering of Starch Biosynthesis The first yield breakthrough achieved in semi-dwarf rice took place through partitioning of photosynthate in favor of grains while the second occurred through an NPT variety that enabled an increase in biomass by manipulating crop geometry but not by enhanced photosynthesis. Recent findings reveal the possibilities of redirecting biosynthetic pathways through recombinant DNA technology enabling plants to produce more or altered quality of natural products such as starch, protein, and lipids. It is now possible to manipulate source-sink equilibrium either by overexpression of endogenous or heterologous enzymes or by down-regulation of endogenous enzymes by using gene silencing techniques.

Manipulation of ADP glucose pyrophosphorylase (ADPGPPase), the key ratelimiting allostearic enzyme in the biosynthetic pathway of starch, for instance, is regarded as a potential strategy to improve yield and starch quality in cereal crops. This enzyme catalyzes glucosyl phosphate into ADP glucose, which is the precursor of starch. Down-regulation of the gene encoding the enzyme by an antisense RNA approach resulting in a drastic decrease in its activity as well as starch accumulation was the first report to establish the crucial role of the enzyme in starch biosynthesis (Lin et al. 1988). The observed increase in starch yield due to antisense inhibition of resident ADPGPPase proved the key regulatory function of the enzyme. Following this report, many researchers explored the possibility of raising yield in other crops by manipulating the enzyme. Believing that natural variability in sink components would be a reflection of the varied behavior of the enzyme, an effort was made to study the extent of variability in the nature of the enzyme in rice. The findings revealed enzyme activity (total and specific), its response to effectors (activator 3PGA and inhibitor Pi), gene expression (transcription), and starch synthesis (total and rate of accumulation) to vary with the genotype and stage of development of the endosperm. Overall evaluation suggests that the highest yielding varieties and highly heterotic hybrids are the most promising in nearly all respects of the enzyme behavior (Devi et al. 2010). More intensive further study of wild/weedy species and ecotypes from different rice ecosystems might result in valuable sources for efficient ADPGPPase for exploitation by even conventional recombination breeding.

Enhancement of Photosynthesis Enhancement of photosynthetic efficiency could be one of the potential means for raising the yield ceiling in rice. In $\mathrm{C}_{3}$ rice, $\mathrm{CO}_{2}$ is assimilated into a 3-carbon compound by the enzyme ribulose-1,5-bisphosphate carboxylase/oxygenase (Rubisco). This enzyme also catalyzes oxidation of RuBP in a wasteful process known as photorespiration, which results in a loss of as much as $25 \%$ of the previously fixed carbon. At temperatures above $30{ }^{\circ} \mathrm{C}$, which are typical of tropical rice-growing areas, the rate of oxygenation increases substantially and this considerably decreases the photosynthetic efficiency of $\mathrm{C}_{3}$ plants by up to 40\% (Ehleringer and Monson 1993). On the contrary, $\mathrm{C}_{4}$ plants have very much decreased rates of photorespiration and thus are adapted to thrive in hot and dry environments; this offers valuable insights for yield improvement strategies. Rice with a $\mathrm{C}_{4}$ photosynthesis mechanism would have increased photosynthetic efficiency while using scarce resources such as land, water, and fertilizer (specifically 
nitrogen) more effectively (Hibberd et al. 2008). As it would perform well under high temperature and require less water and nitrogen, $\mathrm{C}_{4}$ rice would benefit varied rice ecosystems, including marginal lands. Engineering the photosynthetic pathway of $\mathrm{C}_{3}$ rice into a $\mathrm{C}_{4}$ plant is quite a challenging and time-consuming task. The main challenge of converting the photosynthetic pathway of a $\mathrm{C}_{3}$ plant into that of a $\mathrm{C}_{4}$ plant lies in decreasing photorespiration and modifying the leaf canopy (anatomy). IRRI, through an ambitious collaborative project (International $\mathrm{C}_{4}$ Rice Consortium) involving advanced countries/laboratories, is engaged in converting $\mathrm{C}_{3}$ rice into a $\mathrm{C}_{4}$ plant by introducing appropriate genes from maize and other $\mathrm{C}_{4}$ plant species. The $\mathrm{C}_{4}$ pathway genes such as $\mathrm{CA}$ (carbonic anhydrase), PEPC (phosphoenolpyruvate carboxylase), PPDK (PEP carboxykinase), NADP-ME (NADP-dependent malic enzyme), and NADP-MDH (NAD-dependent malate dehydrogenase) cloned from maize are being engineered into rice. Also, the transporters that were overexpressed in the $\mathrm{C}_{4}$ metabolic pathway such as 2-oxoglutarate/malate transporter (OMT1), dicarboxylate transporter1 (DiT1), dicarboxylate transporter2 (DiT2), PEP/phosphate transporter (PPT1), mesophyll envelope protein (MEP), and triose-phosphate phosphate translocator (TPT) and that were identified through proteomics of maize bundle sheath and mesophyll cells (Friso et al. 2010) were transformed into rice. Models show that increased water and nitrogen use efficiencies from this engineering effort could result in yield increases of 30\% to 50\% (Karki et al. 2013). Wang et al. (2017a, b), in their theoretical analysis of biochemical and anatomical factors, demonstrated that integrating a $\mathrm{C}_{4}$ metabolic pathway into rice leaves with a $\mathrm{C}_{3}$ metabolism and mesophyll structure may lead to increased photosynthesis under current ambient $\mathrm{CO}_{2}$ concentration. Also, they concluded that the partitioning of energy between $\mathrm{C}_{3}$ and $\mathrm{C}_{4}$ photosynthesis and the partitioning of Rubisco between mesophyll and bundle sheath cells would be decisive factors controlling photosynthetic efficiency in an engineered $\mathrm{C}_{3}-\mathrm{C}_{4}$ leaf.

In yet another attempt to enhance photosynthesis and thereby genetic yield, Ambavaram et al. (2014) identified a master regulator, HYR (HIGHER YIELD RICE), a transcription factor associated with photosynthetic carbon metabolism (PCM). It directly activates the photosynthetic pathway genes and other downstream genes involved in PCM and yield stability under drought and hightemperature environmental stress conditions. Haritha et al. (2017) reported wild introgressions from O. rufipogon to increase the photosynthetic efficiency of KMR3 rice lines.

\subsection{Defending Against Biophysical Stresses}

Hardly any crop plant is challenged by diverse biotic and abiotic stresses as rice is. The crop is vulnerable to more than one dozen pathogens and as many insect pests, many of which exist in virulent/viruliferous races/biotypes. As for abiotic stresses, diverse stressful water regimes in rainfed lowlands, moisture-deficit rainfed uplands, coastal saline and inland sodic soils, temperature extremes, etc. constitute the major 
stresses, covering $45 \%$ of the world's rice area. Climate change is yet another threat to agriculture in general and rice in particular.

Breeding for Resistance to Biotic Stresses Since the introduction of high-yielding semi-dwarf varieties, diseases and insect pests have been increasingly causing severe yield losses year after year. Among pathogens, blast, bacterial leaf blight, sheath blight, and Rice Tungro Virus (RTV), and insect pests yellow stem borer, brown planthopper, leaf folder, and gall midge are the most devastating. Management of these pests has been largely through resistance breeding, taking advantage of race-/biotype-specific resistance genes identified in the gene pool and the adoption of rational gene deployment strategies. Frequent breakdown of resistance in multiracial/multi-biotype pests has made pest management all the more difficult and challenging.

Breeding for Resistance against Diseases Rice blast caused by the fungus Magnaporthe oryzae is the most widespread and devastating disease of rice. Existing in as many as 30 races, it has been managed for many decades mainly by resistance breeding using more than 100 resistance genes identified in the rice gene pool. Nevertheless, the disease is still a challenge because of the frequent breakdown of resistance warranting the need for varieties with broad-spectrum resistance. Pyramiding of genes matching region-specific races was chosen as the strategy to manage the problem and molecular marker technology has been found handy in this effort. Following the pioneering attempts to introgress resistance genes (Pil, $\mathrm{Pi}$-5, $\mathrm{Piz}$, and Pita) by marker-assisted backcross breeding into varieties such as Co39 (Hittalmani et al. 2000), IR50 (Narayanan et al. 2002), and Zhenshan 97A (Liu et al. 2003), this strategy is being adopted globally to make varieties stable against the disease.

Bacterial leaf blight (BLB), caused by Xanthomonas oryzae pv. oryzae (Xoo), is the most serious disease worldwide and it causes yield losses up to $70 \%$. Based on analyses of phenotypic responses to Xoo races and molecular mapping results, 41 genes ( 29 dominant and 12 recessive) conferring resistance to the disease have been registered in the Oryzabase database (www.shigen.nig.ac.jp/rice/oryzabase/gene/ list). Additionally, some R genes/alleles have been generated by mutation breeding. They include nine isolated genes (Xa1, xa5, xa13, Xa21, Xa23, xa25, Xa26/Xa3, $\mathrm{Xa27}$, and $\mathrm{Xa41}$ ) and nine fine-mapped genes (Xa2, Xa4, Xa7, Xa22, Xa30, Xa33, Xa38, Xa39, and Xa40) (www.shigen.nig.ac.jp/rice/oryzabase/gene/list). In addition to such Mendelian genes, QTLs for resistance have been reported. Many pathotype-specific resistance genes linked to molecular markers have been successfully used for selective improvement of popular high-yielding quality rice varieties such as BPT5204 (Samba Mahsuri) introgressed with Xa21, xa13, and xa5 (Sundaram et al. 2008) and Pusa Basmati-1 introgressed with Xa21 and xal3 (Joseph et al. 2004). The strategy of marker-assisted introgression of dominant genes $(\mathrm{Xa} 4, \mathrm{Xa}$, and $\mathrm{Xa21})$ against BLB has been extended as well to the parental lines of popular hybrids (Borines et al. 2000; Zhang et al. 2006). Recently, Hajira et al. (2016) developed a single-tube, functional marker-based multiplex PCR assay for simultaneous detection of the major BLB resistance genes Xa21, xa13, and $x a 5$ 
in rice. Pyramiding diverse resistance genes against any disease is considered a promising strategy for ensuring broad-spectrum resistance and slowing down the breakdown of resistance. As for the choice of gene sources, many of those accessed from wild/weedy germplasm appear to be of multi-racial/multi-pathotype resistance. For instance, $\mathrm{Xa21}$, which provides resistance to as many as 30 pathotypes and shows synergism with country-/region-specific critical resistance genes, is from O. longistaminata, an African A-genome species, while Xa30 and Xa31, offering resistance to many pathotypes, are from O. nivara, and Xa34 is from O. rufipogon. Better understanding of the molecular mechanisms underlying bacterial pathogenesis that has revealed the role of several factors facilitating infection and progression of the disease might pave the way in the near future to the development of an effective and environmentally safe strategy to manage BLB.

Rice Tungro Virus (RTV), the most dreaded disease induced by mixed infection of Rice Tungro Bacilliform Virus (RTBV) and Rice Tungro Spherical Virus (RTSV), is transmitted by green leafhopper. Screening of a large number of rice germplasm accessions reveals many traditional varieties to be resistant to RTSV and only a few to RTBV (Shim et al. 2015). RTSV resistance is a recessive trait controlled by a translation initiation factor4 gamma (eIF4G) located on chromosome 7 (Lee et al. 2010). A few years ago, an RTSV resistance gene was transferred to japonica rice by marker-assisted selection (Shim et al. 2015). Initially, the disease was managed by host-plant resistance breeding using a few accessions as donors. Recent studies show that the RNA interference (RNAi) technique would be more effective and could be used to develop virus-resistant transgenic rice. Le et al. (2015) generated transgenics capable of producing small interfering RNA specific against RTSV sequences. In order to develop transgene-based resistance against RTBV, Valarmathi et al. (2016) used the ORF IV gene by RNA-interference in rice variety Pusa Basmati-1, and the transgene was subsequently introgressed into ASD 16, a variety popular in southern India, by marker-assisted breeding.

Against sheath blight (ShB), which was once a minor disease but is now a major one, no source of resistance has as yet been found. However, as many as 50 QTLs with moderate resistance have been mapped. Several studies have reported candidate genes for resistance such as chitinase, glucanase, glutathione S-transferase, and kinase protein to be within the mapped QTL region (Yadav et al. 2015). Although most of the sheath blight resistance QTLs identified so far are of only limited effect on $\mathrm{ShB}$, reports showing an expected level of resistance were not uncommon. For instance, Zuo et al. (2007) reported introgression of the QTL qSB-11LE to decrease grain loss by $10.71 \%$ in the background of variety Lemont under severe disease conditions in field trials. Pinson et al. (2005) predicted $q S B-9^{T Q}$ and $q S B-3^{T Q}$ to decrease crop loss due to the disease by $15 \%$ when introduced into the same variety. Wang et al. (2012a, b) found pyramiding of diverse sheath blight resistance QTLs such as $q S B 9-2$ and $q S B 12-1$ to increase resistance. Interestingly, Zuo et al. (2014) reported that pyramiding of the QTLs $q S B-9^{T Q}$ and $T A C 1^{T Q}$, governing stem borer resistance and tiller angle (TA), respectively, improved resistance to ShB. Thus, in the absence of R genes, pyramiding of ShB moderate resistance QTLs and of other QTLs governing unrelated traits/stresses could be worth attempting as an alternative strategy to manage the disease, as reported by Zuo et al. (2014). In addition to such 
host resistance-based strategies, a transgenic approach through inhibition of chitin metabolism in fungi such as Rhizoctonia solani, by expression of rice chitinase, could be a strategy for controlling the disease. Karmakar et al. (2017) demonstrated that transgenics overexpressed with constructs pyramided with two genes, OsCHIII (chitinase gene) and AtNPRI (Arabidopsis NPR1), were superior to a single-gene cassette in enhancing sheath blight tolerance.

Breeding for Resistance against Insect Pests Rice hosts more than one dozen insect pests, of which stem borer, brown planthopper, white backed planthopper, leaf folder, and gall midge cause serious yield losses. The host-plant resistance available in abundance against all the major insect pests and their biotypes with the exception of stem borer and leaf folder has enabled breeders to manage them so far by sequentially releasing resistant varieties matching newly emerging biotypes. Nevertheless, the emergence of newer and increasingly viruliferous biotypes requiring matching resistance gene sources, occurrence of more than one pest/biotype in any given region, and still no way to find resistance gene sources against yellow stem borer and leaf folder have made insect pest management a challenging task. Given the limitations of the conventional breeding-selection approaches, more rational gene deployment such as molecular marker-aided resistance gene pyramiding and introgression of novel alien genes by recombinant DNA technology are now employed/contemplated for effective management of insect pest problems. Many of the insect pest-/biotype-specific resistance genes have been mapped and linked to closely placed markers. For engineering resistance, many different insecticidal proteins and molecules known to be highly selective in their action against a given pest, causing no harm to non-target organisms, are being experimented with. Among the widely used genes encoding insecticidal proteins/molecules against rice insect pests, endotoxin crystal proteins of Bacillus thuringiensis, digestive enzymespecific protease inhibitors, plant lectins, $\alpha$ amylase inhibitors, insect chitinases, and insecticidal viruses are important. Of these, $B t$ toxin genes (cry IA, cry IB, cry $I C$, etc.) and protease inhibitors (cowpea serine PI) against stem borer and lectin protein gene (gna, asa lectin) against hoppers have been reported to be effective. Advances made in managing various insect pests are presented hereunder.

Yellow stem borer (Scirpophaga incertulas) (Walker) is the most important insect pest globally in rice-producing areas. As there are no strong host-resistance gene sources against it, genetic engineering approaches have been attempted and found promising. Datta et al. (1996) and Nayak et al. (1997) were the first to report transformation of rice with the $B t$ gene against yellow stem borer. Since then, several workers have successfully engineered rice with different $B t$ genes (cry $I A(b)$, cry $I A(c)$, and cry IAb) alone as well as in fusion forms against the pest. Liu et al. (2016) pyramided two foreign genes, crylAc driven by rice Actin $I$ promoter and lysine-rich protein (LRP) driven by endosperm-specific GLUTELIN1 (GT1) promoter, into elite indica cultivar 9311. In the pyramided line, $c r y l A c$ has been found to efficiently express in leaves and stems against striped stem borer (Chilo suppressalis Walker) under laboratory conditions and against rice leaf folder (Cnaphalocrocis medinalis Guenee) under field 
conditions. Despite such success stories elsewhere, including in China, Spain, Pakistan, etc., Bt rice is yet to be deregulated for commercial planting.

Brown planthopper (BPH), Nilaparvata lugens Stål, has been a threat to rice production in Asia since the advent of high-yielding varieties. Experience with its management shows host-plant resistance to be the most efficient and sustainable strategy. As of now, $31 \mathrm{BPH}$ resistance genes have been identified in cultivars and wild species and all except $b p h 5$ and $b p h 8$ have been mapped to various chromosomes of rice. To date, $13 \mathrm{BPH}$ resistance genes (Bph14, Bph3, Bph15, Bph26/2, bph29, Bph18, Bph9/1/7/10/21, and Bph32) have been identified and characterized via a map-based cloning approach (Jing et al. 2017). Many of the genes have been introduced alone or in combination into modern rice varieties/parental lines of hybrids by marker-assisted selection. Wang et al. (2017a, b) pyramided Bph6 and Bph9 into elite restorer line 93-11, while Fan et al. (2017) developed three broadspectrum BPH-resistant restorer lines by pyramiding big-panicle gene Gn8.1, BPH resistance genes $B p h 6$ and $B p h 9$, and fertility restorer genes $R f 3$, $R f 4, R f 5$, and $R f 6$ through molecular marker-assisted breeding.

Besides the gene pyramiding strategy to develop broad-spectrum hopper-resistant varieties, genetic engineering approaches have been attempted. For instance, Nagadhara et al. (2004) successfully engineered Chaitanya variety with gna lectin protein and another variety with onion/garlic lectin (asa lectin) (Saha and Majumder 2006). To develop durable resistance against BPH, green leafhopper, and whitebacked planthopper, ASACI and GNA protein genes have been pyramided by crossing single-gene-based transgenic lines. The lines developed so far have been found to surpass in their level of resistance in all three hoppers vis-à-vis single-gene-based transgenics (Rao et al. 1998).

Asian rice gall midge (GM) (Orseolia oryzae Wood-Mason) is a serious pest in rice-growing countries, especially in China, India, and Sri Lanka. To date, 11 GM resistance genes ( $\mathrm{Gm} 1, \mathrm{Gm} 2, \mathrm{gm} 3, \mathrm{Gm} 4, \mathrm{Gm} 5, \mathrm{Gm} 6, \mathrm{Gm} 7, \mathrm{Gm} 8, \mathrm{Gm} 9$, Gm10, and $\operatorname{Gml1}(t))$ have been identified and characterized. As for their pyramiding to realize broad-spectrum resistance against more than one biotype, Nair et al. (2011) demonstrated that stacking of $G m l$ with any one of the genes in group II, which exclude $G m 4$ and $G m 7$, would confer resistance to five biotypes (GMB1, GMB2, GMB3, $G M B 5$, and $G M B 6$ ). To cover all the biotypes, at least three genes, preferably $G m l$, $G m 2$, and $G m 4$, would be required.

Rice leaffolder (RLF) (Cnaphalocrocis medinalis Guenee) is another major insect pest. Developing RLF-resistant lines in rice through conventional breeding has been a challenge due to the non-availability of a host-plant resistance gene. Alternatively, genetic engineering has been attempted by introducing heterologous insecticidal genes. Manikandan et al. (2016) succeeded in developing transgenic rice resistant to the pest with codon optimized synthetic cry $2 A X 1$ gene fused with a rice chloroplast transit peptide sequence. In another report, Chakraborty et al. (2016) demonstrated that transgenic rice expressing the cry $2 A X 1$ gene conferred resistance to multiple lepidopteran pests, including RLF. Pradhan et al. (2016) also reported transgenic rice expressing vegetative insecticidal protein (Vip) of Bacillus thuringiensis to show broad insecticidal properties. 
Breeding for Tolerance of Abiotic Stresses Among abiotic stresses that severely depress productivity, drought, submergence, and salinity are important. The plant's ability to withstand such stresses results from the cumulative effects of a network of physiological and biochemical functions. Negative effects of abiotic stresses include broadly stress-imposed homeostasis imbalance, disruption of growth and metabolic activities, and generation of cell-damaging reactive oxygen species (ROS). At the molecular level, plants under abiotic stresses adapt to the conditions by triggering a cascade of events that start with stress perception and end with the expression of a battery of genes of adaptive response. Adaptation at the molecular level is through restoration of homeostasis (ion and osmotic gradient), control of damage, and detoxification of ROS. Knowledge of the genetics governing these stresses is a prerequisite for finding solutions to the problem. Unlike resistance to biotic stresses that largely follows a Mendelian mode of inheritance, tolerance of abiotic stresses is quite complex and polygenically controlled. Added to the inadequate knowledge of genetics, a lack of reliable and reproducible screening/selection techniques has made breeding all the more challenging, despite having sources of resistance in the rice gene pool. As a result, more than $60 \%$ of the global rice area, especially in the rainfed ecosystem does not have as yet high-yielding varieties ideally suited to this harsh environment. For the past 15 years, advances in plant molecular biology have provided breeders with a variety of genomic tools and resources capable of overcoming the technological constraints that have been impeding progress in finding genetic solutions to such stresses.

Of the estimated huge future rice demand, most production has to come from rainfed lowland and upland rice ecosystems, where drought is the major yield constraint. Unlike the irrigated ecosystem, no truly high-yielding varieties are adapted to drought stress. In drought-prone parts of the world, farmers have no option but to grow traditional low-yielding but well-adapted varieties. All efforts to develop highyielding drought-tolerant varieties by using traditional drought-tolerant varieties as donor sources proved a futile exercise. This is largely on account of the genetically complex nature of drought tolerance and dependence on phenotype-based selection. Major indices of tolerance QTLs now mapped and linked to robust markers have made genotype-based selection and pyramiding of varieties with tolerance QTLs easy and efficient.

Several QTLs relating to different parameters of drought tolerance such as osmotic adjustment, cell membrane stability, relative water content, root characteristics, and stress recovery as well as yield per se under stress have been mapped and linked to robust markers. Among the traits that govern drought tolerance, the direct measure of grain yield under drought rather than its component traits is promising. As of now, a large number of QTLs governing grain yield under drought (DTY) have been identified, such as $q D T Y 12.1, q D T Y 3.1, q D T Y 6.1, q D T Y 2.2$, and $q D T Y 9.1$. The various combinations of these DTY QTLs resulted in an average yield advantage of 300-500 kg/ha under stress conditions. For instance, the major-effect QTL $q D T Y_{12.1}$ has been introgressed into Vandana and it has a yield advantage of about $500 \mathrm{~kg} / \mathrm{ha}$ over its donor parent under reproductive-stage stress (Kumar et al. 2014). 
Similar success has been achieved by introgressing the QTL $q D T Y s$ into droughtsusceptible mega-variety IR64 (Swamy and Kumar 2013). Two QTLs ( $q D T Y 3.2$ and $q D T Y 12.1$ ) with large effects for grain yield under drought have been transferred into Sabitri, a popular variety of Nepal, through marker-assisted breeding (Dixit et al. 2017). Many more QTLs have been identified for yield under drought conditions and they are being transferred to the background of popular high-yielding varieties such as Swarna, IR64, Vandana, Sabitri, TDK1, Anjali, Samba Mahsuri, MRQ74, MR219, Jinmibyeo, Gayabyeo, Hanarumbyeo, and Sangnambatbyeo by marker-assisted breeding at IRRI and other centers. Besides these DTY QTLs, Uga et al. (2013) reported that the QTL Deeper Rooting 1 (DRO1) increased root growth angle in rice, leading to higher yield under drought conditions.

Given the availability of many novel genes conferring high tolerance of the stress along with efficient transformation-regeneration protocols in place, genetic engineering for drought tolerance has been found to be a distinct possibility. Candidate genes used with some success in rice are trehalose (tps) cloned from Arabidopsis, trehalose-6-phosphate synthase, and trehalose-6-phosphate phosphatase (tps 1 ) from yeast, pyrroline carboxylate synthase $(P 5 c b)$ from Vigna aconitifolia, chloroplast glutamine synthetase (GS2) from rice, and choline oxidase (glycine-betaine synthesis) ( $\operatorname{cod} A)$ from Arthrobacter globiformis. Among the regulatory genes, DRE binding protein $($ drebl $\alpha$ ), calcium-dependent protein kinase (OsCDPK7), and those identified with cellular-level tolerance such as helicases (PDH45) and APZ/ERF family DREB transcription factors are important (Saijo et al. 2000; Sahoo et al. 2012; Rashid et al. 2012).

Although many sources of tolerance of salt stress are available in native germplasm such as SR26B, Nona Bokhra, and Pokkali, efforts to combine the desired level of tolerance in high-yield backgrounds by conventional breeding yielded no tangible results. Convinced of the potential of molecular marker-assisted breeding and gene transfer technology, possibilities have been explored to find genetic solutions to the problem. As no single QTL/gene could provide the desired level of tolerance, pyramiding of genes for tolerance-related morpho-physiological features ( $\mathrm{Na}$ and $\mathrm{Cl}$ exclusion, $\mathrm{K}$ uptake, $\mathrm{N} / \mathrm{K}$ ratio, and tissue tolerance) and biochemical pathways (glyoxalase, abscisic acid, proline, glycine-betaine, and polyamine) has been employed. More than 80 salt-tolerance QTLs with large effects have been mapped so far. Of these, Saltol mapped in Pokkali is a major one and it has already been transferred to high-yielding varieties such as BR11, BRRI dhan28, IR64, and AS996 (Babu et al. 2017).

The genetic engineering strategy is based on genes/enzymes involved in the pathways of (a) osmosis homeostatic balance, wherein ion and osmatic gradient are restored; (b) detoxification by scavenging of ROS; and (c) stress damage control restoring growth and metabolic activities. Transgenics with relevant salt-tolerance genes obtained from various sources have been reported to adapt well to and survive in saline soils. Many important genes conferring salt tolerance belong to the salt overly sensitive (SOS) pathway. Of the several candidate and regulatory genes overexpressed in rice, calcium-dependent protein kinase $(O s C D P K)$, a transcription factor, choline oxidase $(\operatorname{cod} A)$ involved in glycine-betaine synthesis, chloroplast 
glutamine synthetase (GS2), pyrroline carboxylate synthetase, etc. are some of the successfully employed sources. Expression of two genes of the glyoxalase pathway, glyI and glyII, preferably together, has been shown to confer tolerance of salinity (Singla-Pareek et al. 2006). Overexpression of several stress-induced genes, including helicases, has been shown to provide tolerance of the stress in rice. Sahoo et al. (2012) have demonstrated pea DNA helicase 45 to promote salinity tolerance in IR64 with higher yield.

Flash floods causing submergence are the major yield-depressing factor in rainfed shallow lowland rice. Depending on the growth stage and period under water, crop damage could vary from 10 to $100 \%$. Unlike traditional tall varieties such as FR13A and FR43B, which are known to adapt to submergence, short-statured highyielding varieties suffer the most, even when the period of submergence is not even a few days. Hence, farmers in the rainfed lowland ecosystem prefer traditional varieties, not minding their low productivity. Despite years of effort to breed submergence tolerance into high-yield backgrounds using FR13A-like donor sources, no progress could be made. This was largely due to the lack of precise knowledge of the genetics of submergence tolerance per se and of the morpho-physiological parameters that govern it and the non-reliability of phenotype-based selection under stress conditions. The major QTL identified in flood-tolerant landrace FR13A and designated as Sub1, which explains $70 \%$ of the phenotypic variance, was mapped onto chromosome 9. A joint international effort involving NRRI and NDUAT in India, BRRI in Bangladesh, University of California-Davis in the United States, and IRRI began for the characterization and use of the QTL in marker-assisted breeding for developing submergence-tolerant varieties. Dissection of the QTL revealed it to be a cluster of three genes encoding ethylene responsive factors designated as SublA, SublB, and SublC. Of these, SublA was identified as the key gene conferring tolerance of submergence. Two alleles of SublA, SublA-1 (tolerance specific) and SublA-2 (intolerance specific) were identified with a single nucleotide polymorphism changing proline to serine (Septiningsih et al. 2009). Swarna selectively introgressed with SublA was formally released for general cultivation as SwarnaSub1A in India (Odisha, Uttar Pradesh, etc.), Bangladesh, the Philippines, and Indonesia. The SublA gene has also been deployed into Thai fragrant rice Khao Dawk Mali 105 and rice restorer line Wanhui 6725 (Luo et al. 2016). This was probably the first example of a biotech product ever developed for abiotic stress conditions by marker-assisted breeding in rice.

Enrichment of Nutritive Quality Enrichment of nutritive quality is as important as yield enhancement on account of people in Asia depending on rice for a sizable part of their nutritional requirement. Because about one-half of the global population is suffering from one or more nutrient deficiency-related health disorders and more than three million children die each year because of malnutrition, there is a need and urgency to pay due attention to the nutritive quality in rice.

Among the nutritional limitations of rice, low protein content (PC) is the foremost. Nevertheless, the need to raise the protein content received no serious attention from breeders after experiencing early failures. Following the identification of 
high-protein donor sources, despite the complex inheritance and the earlier reported negative relationship between yield and protein content, breeders have started believing that high protein content could be combined with high yield. By using ARC10075 as a donor, CR Dhan310 (IET24780) with PC of 11\% and rich in threonine and lysine content has been developed and released for general cultivation in India (Mahender et al. 2016). Although many efforts have been made for developing marker-assisted breeding for high PC, success has so far been eluded. Xu et al. (2017) were successful in developing transgenic rice with enhanced high-quality protein content by expressing the $A m A l$ gene from Amaranthus sp.

Vitamin deficiency-related health disorders are widespread in third world countries. Vitamin A deficiency causing vision impairment is especially rampant. In the absence of exploitable natural variability, in all food grains except maize, alternative strategies have to be found. Professor Ingo Potrykus of the Federal Institute of Plant Sciences, Switzerland, jointly with Professor Peter Beyer of the University of Freiburg, Germany, succeeded in raising $\beta$ carotene content by an ingenious genetic engineering strategy. The strategy lay in restoring three critical genes that are missing in the isoprenoid pathway of carotene synthesis by accessing them from daffodil (phytoene synthase ( $p s y)$, phytoene desaturase $(p d s)$, and lycopene cyclase $(l y c)$ ), and the bacterium Erwinia uredovora (carotene desaturase, crt1) (Ye et al. 2000). So, the transformed rice popularly known as Golden rice, although a great scientific achievement, accumulates far less $(1.6 \mathrm{mg} / \mathrm{g})$ beta carotene. Understanding that it was due to the use of relatively less efficient daffodil gene $p s y$ encoding phytoene synthase, the multinational biotech company Syngenta succeeded in increasing the content of $\beta$ carotene by several fold ( $37 \mathrm{mg} / \mathrm{g}$ ) by using the $p s y$ gene cloned from maize (Paine et al. 2005). Sadly, the Golden rice developed close to 20 years ago has yet to be deregulated for commercial planting because of regulatory hurdles.

As for mineral nutrients, iron and zinc are the most crucial as their deficiency is the main cause of malnutrition. Modern high-yielding varieties are low in these two mineral nutrients. On average, Fe content in polished rice is $2 \mathrm{mg} / \mathrm{kg}$ vis-à-vis the recommended dietary intake for humans of $10-15 \mathrm{mg} / \mathrm{kg}$. In the case of $\mathrm{Zn}$, males within the age bracket of 15-74 years require on average 12-15 mg/day vis-à-vis $68 \mathrm{mg} /$ day required for females (Mahender et al. 2016). Conventional breeding for developing Fe-enriched rice has not progressed to the desired extent due to limited variability for $\mathrm{Fe}$ content in polished rice. Evaluation of more than 20,000 rice accessions from Asia, Latin America, and the Caribbean for Fe and Zn content revealed a maximum of only $8 \mathrm{mg} / \mathrm{kg}$ in polished grains. This is because most of the Fe and $\mathrm{Zn}$ are concentrated in the aleurone and sub-aleurone layers of rice kernels, and is lost upon polishing. Taking advantage of Zn-rich donor sources, under the HarvestPlus project, the Bangladesh Rice Research Institute in collaboration with IRRI developed and released two Zn-enriched (19 and $24 \mathrm{mg} / \mathrm{kg}$ ) varieties. The Indian Institute of Rice Research, Hyderabad, has as well succeeded in developing three rice varieties (DRR Dhan 45, DRR Dhan 48, and DRR Dhan 49) with high Zn content: 22.3, 20.91, and $26.13 \mathrm{mg} / \mathrm{kg}$, respectively (Rao et al. 2020). Many low to moderate Zn QTLs have now been mapped in the germplasm. In addition, genomewide association mapping and QTL mapping enabled the identification of several 
loci associated with grain Fe and Zn content (Norton et al. 2014; Swamy et al. 2018; Calayugan et al. 2020).

Transgenic approaches to enhance Fe content in rice grains were first explored more than a decade ago. Since then, attempts have been made to increase Fe content in rice endosperm by overexpressing the genes involved in Fe uptake from soil and those involved in translocation from aerial parts to grains. Among these studies, a concomitant increase in Fe and $\mathrm{Zn}$ content in rice grains was obtained by overexpression or activation of NAS (nicotianamine synthase) genes, either in solo or in combination with other transporters or Fe storage genes. Constitutive expression of OsNAS2 has been reported to result in increased Fe content $(19 \mathrm{mg} / \mathrm{kg})$ and $\mathrm{Zn}$ concentration $(76 \mathrm{mg} / \mathrm{kg}$ ) in polished rice grains (Johnson et al. 2011).

\subsection{Selective Modification of Traits by Gene Editing}

Aside from the marker-assisted introgression of genes of interest discussed in the foregoing, an alternative genetic engineering approach for selectively transforming crops with targeted genes has opened up yet another molecular strategy known as genome editing. Genome editing tools such as TALENs (Transcription ActivatorLike Effector Nucleases) and CRISPR/Cas9 (Clustered Regularly Interspaced Short Palindromic Repeats) enable selective interchange of genes of interest. Considered as a non-transgenic method, products thereby are devoid of any foreign material in their final product DNA. Employing these techniques, targeted gene editing for important traits is on the rise. TALENs, for instance, have been used for enhancing seed storability and herbicide resistance in rice by precisely editing the LOX3 gene (Ma et al. 2015) and acetolactate synthase gene (OSALS) (Li and Liu 2016), respectively. Likewise, CRISPR/Cas9 has been used to manipulate traits such as herbicide resistance (Xu et al. 2014), yield components ( $\mathrm{Li}$ et al. 2016), blast resistance (Wang and Wang 2016), TGMS line development (Zhou et al. 2016), stomatal development (Yin and Biswal 2017), and modifying amylose content (Sun et al. 2017; Perez et al. 2019) (Table 2).

\section{Conclusions}

For predominantly rice-consuming Asia to emerge and remain a food-/nutritionsecure continent, sustained self-sufficiency is crucial. Meeting future demand projections sustainably is the challenging task in the face of shrinking natural resources - arable land area, irrigation water, genetic variability — and the inevitable adverse effects of climate change. For the next breakthrough to meet future food demand projections, it seems imperative to exploit advanced cutting-edge tools, which enables development of high yielding, nutrient rich and input-use-efficient designer rice varieties. 
Table 2 Targeted editing of important genes employing genome editing techniques

\begin{tabular}{|c|c|c|c|}
\hline Trait & Targeted gene & $\begin{array}{l}\text { Gene editing } \\
\text { method }\end{array}$ & Reference \\
\hline $\begin{array}{l}\text { Herbicide resistance (resistance to } \\
\text { bentazon and sulfonylurea } \\
\text { herbicides) }\end{array}$ & BEL & $\begin{array}{l}\text { CRISPR-Cas9 } \\
\text { system }\end{array}$ & $\begin{array}{l}\text { Xu et al. } \\
(2014)\end{array}$ \\
\hline Improvement of seed storability & LOX3 & TALENs & $\begin{array}{l}\text { Ma et al. } \\
(2015)\end{array}$ \\
\hline $\begin{array}{l}\text { Regulators of grain number, panicle } \\
\text { architecture, grain size, and plant } \\
\text { architecture }\end{array}$ & $\begin{array}{l}\text { Gn1a, DEP1, GS3, } \\
\text { and IPA1 }\end{array}$ & $\begin{array}{l}\text { CRISPR/Cas9 } \\
\text { system }\end{array}$ & $\begin{array}{l}\text { Li et al. } \\
\text { (2016) }\end{array}$ \\
\hline Herbicide resistance & $\begin{array}{l}\text { Acetolactate } \\
\text { synthase gene } \\
\text { (OsALS) }\end{array}$ & TALENs & $\begin{array}{l}\text { Li and Liu } \\
\text { (2016) }\end{array}$ \\
\hline Blast resistance & OsERF922 & CRISPR/Cas9 & $\begin{array}{l}\text { Wang and } \\
\text { Wang (2016) }\end{array}$ \\
\hline TGMS line development & TMS5 & CRISPR/Cas9 & $\begin{array}{l}\text { Zhou et al. } \\
(2016)\end{array}$ \\
\hline Stomatal development & EPFL9 & $\begin{array}{l}\text { CRISPR/Cas9 } \\
\text { and CRISPR/ } \\
\text { Cpf1 }\end{array}$ & $\begin{array}{l}\text { Yin et al. } \\
\text { (2017) }\end{array}$ \\
\hline High amylose content & SBEI and SBEII & CRISPR/Cas9 & $\begin{array}{l}\text { Sun et al. } \\
(2017)\end{array}$ \\
\hline Low amylase content & GBSS & CRISPR/Cas9 & $\begin{array}{l}\text { Perez et al. } \\
(2019)\end{array}$ \\
\hline
\end{tabular}

\section{References}

Ahn SN, Kwon SJ, Suh JP, Kang KH, Kim HJ, Hwang HG, Moon HP (2003) Introgression for agronomic traits from $O$ grandiglumis into rice, $O$ sativa. In: Mew TW, Brar DS, Peng S, Dawe D, Hardy B (eds) Rice science: innovations and impact for livelihood. International Rice Research Institute (IRRI), Los Baños, pp 265-274

Ali J (1993) Studies on temperature sensitive genic male sterility and chemical induced sterility towards development of two-line hybrids in rice (Oryza sativa L.). $\mathrm{PhD}$ thesis, Indian Agricultural Research Institute, New Delhi

Ali J, Siddiq EA, Zaman FU, Abraham MJ, Ahmed IM (1995) Identification and characterization of temperature-sensitive genic male sterile sources in rice (Oryza sativa $\mathrm{L}$ ). Indian J Genet $55: 243-259$

Ali J, Xu JL, Gao Y, Fontanilla M, Li Z (2012) Enhanced productivity across different rice ecologies through green super Rice (GSR) breeding strategy. International Dialogue on Designer Rice for Future, ICRISAT, Hyderabad, 9-10 July 2012

Ambavaram MMR, Basu S, Krishnan A, Ramegowda V, Batlang U, Rahman L, Baisakh N, Pereira A (2014) Coordinated regulation of photosynthesis in rice increases yield and tolerance to environmental stress. Nat Commun 5:5302. https://doi.org/10.1038/ncomms6302

Ando T, Yamamoto T, Shimizu T et al (2008) Genetic dissection and pyramiding of quantitative traits for panicle architecture by using chromosomal segment substitution lines in rice. Theor Appl Genet 116(6):881-890. https://doi.org/10.1007/s00122-008-0722-6

Ashikari M, Sakakibara H, Lin S, Yamamoto T, Takashi T, Nishimura A, Angeles ER, Qian Q, Kitano H, Matsuoka M (2005) Cytokinin oxidase regulates rice grain production. Science 309(5735):741-745. https://doi.org/10.1126/science.1113373 
Babu NN, Krishnan SG, Vinod KK, Krishnamurthy SL, Singh VK, Singh MP, Singh R, Ellur RK, Rai V, Bollinedi H, Bhowmick PK, Yadav AK, Nagarajan M, Singh NK, Prabhu KV, Singh AK (2017) Marker aided incorporation of Saltol, a major QTL associated with seedling stage salt tolerance, into Oryza sativa 'Pusa Basmati 1121'. Front Plant Sci 8:41. https://doi.org/10.3389/ fpls.2017.00041

Borines LM, Veracruz CM, Redoña ED, Hernandez JF, Natural MP, Raymundo AD, Leung H (2000) Marker aided pyramiding of bacterial blight resistance genes in maintainer lines for hybrid rice production. International Rice Research Institute Conference Abstract 4:162

Brondani C, Rangel PHN, Brondani RPV, Ferreira ME (2002) QTL mapping and introgression of yield-related traits from Oryza glumaepatula to cultivated rice (Oryza sativa L.) using microsatellite makers. Theor Appl Genet 104:1192-1203

Calayugan MIC, Formantes AK, Amparado A et al (2020) Genetic analysis of agronomic traits and grain iron and zinc concentrations in a doubled haploid population of rice (Oryza sativa L.). Sci Rep 10:2283. https://doi.org/10.1038/s41598-020-59184-z

Chakraborty M, Reddy PS, Mustafa G, Rajesh G, Narasu VM, Udayasuriyan V, Rana D (2016) Transgenic rice expressing the cry2AX1 gene confers resistance to multiple lepidopteran pests. Transgenic Res 25(5):665-678. https://doi.org/10.1007/s11248-016-9954-4. Epub 2016 Mar 26

Chin HJ, Lu X, Haefele SM, Gamuyao R, Ismail AM, Wissuwa M, Heuer S (2010) Development and application of gene-based markers for the major rice QTL Phosphate uptake 1 (Pup1). Theor Appl Genet 120:1073-1086

Datta K, Torrizo L, Oliva N, Alam MF, Wu C, Abrigo E, Vasquez A, Tu J, Quimia C, Alejar M, Nicola Z, Khush GS, Datta SK (1996) Production of transgenic rice by protoplast, biolistic and Agrobacterium systems. In: Proceedings of the fifth international symposium on rice molecular biology. Yi Sein Publishing Co., Taipei, pp 159-167

Devi T, Anjana N, Sarla B, Siddiq EA, Sirdeshmukh R (2010) Activity and expression of adenosine diphosphate glucose pyrophosphorylase in developing rice grains: varietal differences and implications on grain filling. Plant Sci 178:123-129

Dingkuhn M, Penning de Vries FWT, De Datta SK, van Laar HH (1991) Concepts for a new plant type for direct seeded flooded tropical rice. Selected papers from the International Rice Research conference, Seoul, Korea, 27-31 August 1990

Dixit S, Yadaw RB, Mishra KK, Kumar A (2017) Marker-assisted breeding to develop the droughttolerant version of Sabitri, a popular variety from Nepal. Euphytica 213:184

Ehleringer JR, Monson RK (1993) Evolutionary and ecological aspects of photosynthetic pathway variation. Annu Rev Ecol Syst 24:411-439

Fan F, Li N, Chen Y, Liu X, Sun H, Wang J, He G, Zhu Y, Li S (2017) Development of elite BPHresistant wide-spectrum restorer lines for three and two line hybrid rice. Front Plant Sci 8:986. https://doi.org/10.3389/fpls.2017.00986

Friso G, Majeran W, Huang MS, Sun Q, van Wijk KJ (2010) Reconstruction of metabolic pathways, protein expression, and homeostasis machineries across maize bundle sheath and mesophyll chloroplasts: large-scale quantitative proteomics using the first maize genome assembly. Plant Physiol 152:1219-1250

Fuji S, Toriyama K (2009) Suppressed expression of Retrograde-Regulated Male Sterility restores pollen fertility in cytoplasmic male sterile rice plants. Proc Natl Acad Sci U S A 106:9513-9518. https://doi.org/10.1073/pnas.0901860106

Fujino K, Hirayama Y, Obara M, Ikegaya T (2019) Introgression of the chromosomal region with the $P i$-cd locus from Oryza meridionalis into $O$. sativa L. during rice domestication. Theor Appl Genet 132:1981-1990

Ganeshan P, Jain A, Parmar B, Rao AR, Sreenu K, Mishra P, Mesapogu S, Subrahmanyam D, Ram T, Sarla N, Rai V (2016) Identification of salt tolerant rice lines among interspecific BILs developed by crossing Oryza sativa $\times O$. rufipogon and $O$. sativa $\times O$. nivara. Aust J Crop Sci 10(2):220-228

Garg AK, Sawers RJ, Wang H et al (2006) Light-regulated overexpression of an Arabidopsis phytochrome A gene in rice alters plant architecture and increases grain yield. Planta 223(4):627-636. https://doi.org/10.1007/s00425-005-0101-3 
Gopalakrishna K, Vemireddy LR, Srividhya A, Nagireddy R, Jena SS, Gandikota M, Patil S, Veeraghattapu R, Deborah DAK, Reddy GE, Shake M, Dasari A, Ramanarao PV, Durgarani CV, Neeraja CN, Siddiq EA, Sheshumadhav M (2017) QTL-Seq-based genetic analysis identifies a major genomic region governing dwarfness in rice (Oryza sativa L.). Plant Cell Rep 37(4):677-687. https://doi.org/10.1007/s00299-018-2260-2

Hajira SK, Sundaram RM, Laha GS, Yugander A, Balachandran SM, Viraktamath BC, Sujatha K, Balachiranjeevi CH, Pranathi K, Anila M, Bhaskar S, Abhilash V, Mahadevaswamy HK, Kousik M, Dilip Kumar T, Harika G, Rekha G (2016) A single-tube, functional marker-based multiplex PCR assay for simultaneous detection of major bacterial blight resistance genes $X a 21, x a 13$ and $x a 5$ in rice. Rice Sci 23(3):144-151

Haritha G, Vishnukiran T, Yugandhar P, Sarla N, Subrahmanyam D (2017) Introgressions from Oryza rufipogon increase photosynthetic efficiency of KMR3 rice lines. Rice Sci 24(2):85-96

Hibberd JM, Sheehy JE, Langdale JA (2008) Using C4 photosynthesis to increase the yield of rice: rationale and feasibility. Curr Opin Plant Biol 11(2):228-231. https://doi.org/10.1016/j. pbi.2007.11.002

Hirabayashi H, Sato H (2010) Development of introgression lines derived from Oryza rufipogon and O. glumaepatula in the genetic background of japonica cultivated rice (O. sativa L.) and evaluation of resistance to rice blast. Breed Sci 60:604-612

Hittalmani S, Parco A, Mew TV, Zeigler RS, Huang N (2000) Fine mapping and DNA markerassisted pyramiding of the three major genes for blast resistance in rice. Theor Appl Genet 100:1121-1128

Huang Y (2001) Rice ideotype breeding of Guangdong Academy of Agricultural Sciences in retrospect. Guangdong Agric Sci 3:2-6. (in Chinese)

Hussain AJ, Ali J, Siddiq EA, Gupta VS, Reddy UK, Ranjekar PK (2011) Mapping of tms8 gene for temperature-sensitive genic male sterility (TGMS) in rice (Oryza sativa L.). Plant Breed 131(1):42-47

Imai I, Kimball JA, Conway B et al (2013) Validation of yield-enhancing quantitative trait loci from a low-yielding wild ancestor of rice. Mol Breed 32:101-120

Itoh H, Tatsumi T, Sakamoto T, Otomo K, Toyomasu T, Kitano H, Ashikari M, Ichihara S, Matsuoka M (2004) A rice semidwarf gene, Tan-Ginbozu (D35), encodes the gibberellin biosynthesis enzyme, ent-kaurene oxidase. Plant Mol Biol 54(4):533-547. https://doi. org/10.1023/B:PLAN.0000038261.21060.47

Jairin J, Sansen K, Wongboon W, Kothcharerk J (2010) Detection of a brown planthopper resistance gene bph4 at the same chromosomal position of Bph 3 using two different genetic backgrounds of rice. Breed Sci 60:71-75. https://doi.org/10.1270/jsbbs.60.71

Jing S, Zhao Y, Du B, Chen R, Zhu L, He G (2017) Genomics of interaction between the brown planthopper and rice. Curr Opin Insect Sci 19:82-87

Johnson AAT, Kyriacou B, Callahan DL, Carruthers L, Stangoulis J, Lombi E et al (2011) Constitutive overexpression of the OSNAS gene family reveals single-gene strategies for effective iron- and zinc-biofortification of rice endosperm. PLoS One 6(9):e24476. https://doi. org/10.1371/journal.pone.0024476

Joseph M, Gopalakrishnan S, Sharma RK, Singh VP, Singh AK, Singh NK, Mohapatra T (2004) Combining bacterial blight resistance and basmati quality characteristics by phenotypic and molecular marker-assisted selection in rice. Mol Breed 13(4):377-387

Kaladhar K, Swamy BPM, Babu AP, Reddy CS, Sarla N (2008) Mapping quantitative trait loci for yield traits in $\mathrm{BC}_{2} \mathrm{~F}_{2}$ population derived from Swarna $\mathrm{x}$ O. nivara cross. Rice Genet Newsl 24:34-36. https://doi.org/10.1093/jhered/esr145

Karki S, Rizal G, Quick WP (2013) Improvement of photosynthesis in rice (Oryza sativa L.) by inserting the C4 pathway. Rice 6:28. https://doi.org/10.1186/1939-8433-6-28

Karmakar S, Molla KA, Das K, Sarkar SN, Datta SK, Datta K (2017) Dual gene expression cassette is superior than single gene cassette for enhancing sheath blight tolerance in transgenic rice. Sci Rep 7:7900. https://doi.org/10.1038/s41598-017-08180-x 
Kumar A, Dixit S, Ram T, Yadaw RB, Mishra KK, Mandal NP (2014) Breeding high-yielding drought-tolerant rice: genetic variations and conventional and molecular approaches. J Exp Bot 65(21):6265-6278. https://doi.org/10.1093/jxb/eru363

Lafitte HR, Guan YS, Shi Y, Li ZK (2007) Whole plant responses, key processes, and adaptation to drought stress: the case of rice. J Exp Bot 58:169-175

Le DT, Chu HD, Sasaya T (2015) Creation of transgenic rice plants producing small interfering RNA of Rice tungro spherical virus. GM Crops Food 6(1):47-53

Lee J-H, Muhsin M, Atienza GA, Kwak D-Y, Kim S-M, De Leon TB, Angeles ER, Coloquio E, Kondoh H, Satoh K et al (2010) Single nucleotide polymorphisms in a gene for translation initiation factor (eIF4G) of rice (Oryza sativa) associated with resistance to Rice tungro spherical virus. Mol Plant-Microbe Interact 23:29-38

Li T, Liu B (2016) TALEN-mediated homologous recombination produces site-directed DNA base change and herbicide-resistant rice. J Genet Genomics 43:297-305

Li JM, Yuan LP (2000) Hybrid rice: genetics, breeding, and seed production. Plant Breed Rev $17: 15-158$

Li M, Li X, Zhou Z et al (2016) Reassessment of the four yield-related genes Gn1a, DEP1, GS3, and IPA1 in rice using a CRISPR/Cas9 system. Front Plant Sci 7:377. https://doi.org/10.3389/ fpls.2016.00377

Liang F, Deng Q, Wang Y et al (2004) Molecular marker-assisted selection for yield-enhancing genes in the progeny of "9311×O. rufipogon" using SSR. Euphytica 139:159-165

Lin TP, Caspar T, Somerville CR, Preiss J (1988) Isolation and characterization of a starchless mutant of Arabidopsis thaliana (L.) Heynh lacking ADP glucose pyrophosphorylase activity. Plant Physiol 86:1131-1135

Liu SP, Li X, Wang CY, Li XH, He YQ (2003) Improvement of resistance to rice blast in Zhenshan 97 by molecular marker-aided selection. Acta Bot Sin 45:1346-1350

Liu X, Zhang C, Li X, Tu J (2016) Pyramiding and evaluation of both a foreign Bacillus thuringiensis and a Lysine-rich protein gene in the elite indica rice 9311. Breed Sci 66(4):591-598

Luo Y, Ma T, Zhang A, Ong KH, Li Z, Yang J, Yin Z (2016) Marker-assisted breeding of the rice restorer line Wanhui 6725 for disease resistance, submergence tolerance and aromatic fragrance. Rice (N Y) 9:66. https://doi.org/10.1186/s12284-016-0139-9

Luu T, Huyen N, Cuc LM, Ismail AM, Ham LH (2012) Introgression of the salinity tolerance QTL Saltol into AS996, the elite rice variety of Vietnam. Am J Plant Sci 3:981-987

Ma L, Zhu F, Li Z et al (2015) TALEN-based mutagenesis of lipoxygenase LOX3 enhances the storage tolerance of rice (Oryza sativa) seeds. PLoS One 10(12):e0143877. https://doi. org/10.1371/journal.pone.0143877

Mackill DJ, Coffman WR, Garrity DP (1996) Rainfed lowland rice improvement. International Rice Research Institute, Los Baños

Mahender A, Anandan A, Pradhan SK et al (2016) Rice grain nutritional traits and their enhancement using relevant genes and QTLs through advanced approaches. Springerplus 5:2086. https://doi.org/10.1186/s40064-016-3744-6

Manikandan R, Balakrishnan N, Sudhakar D, Udayasuriyan V (2016) Transgenic rice plants expressing synthetic cry $2 A X 1$ gene exhibit resistance to rice leaffolder (Cnaphalocrosis medinalis). 3 Biotech 6(1):10

Marri PR, Sarla N, Vemireddy LR, Siddiq EA (2005) Identification of yield enhancing quantitative trait loci (QTLs) from Oryza rufipogon of Indian origin. BMC Genet 6:33

Mi J, Li G, Huang J, Yu H, Zhou F, Zhang Q, Ouyang Y, Mou T (2016) Stacking S5-n and f5-n to overcome sterility in indica-japonica hybrid rice. Theor Appl Genet 129(3):563-575. https:// doi.org/10.1007/s00122-015-2648-0. Epub 2015 Dec 24

Murai M, Takamure I, Sato S, Tokutome T, Sato Y (2002) Effects of the dwarfing gene originating from 'Dee-geo-woo-gen' on yield and its related traits in rice. Breed Sci 52:95-100

Nagadhara D, Ramesh S, Pasalu IC et al (2004) Transgenic rice plants expressing the snowdrop lectin gene (gna) exhibit high-level resistance to the whitebacked planthopper (Sogatella furcifera). Theor Appl Genet 109(7):1399-1405. https://doi.org/10.1007/s00122-004-1750-5 
Nair S, Bentur JS, Sama VSAK (2011) Mapping gall midge resistance genes: towards durable resistance through gene pyramiding. In: Muralidharan K, Siddiq EA (eds) Genomics and crop improvement: relevance and reservations. Institute of Biotechnology, ANGR Agricultural University, Hyderabad, pp 256-264

Narayanan NN, Baisakh N, Vera Cruz N, Gnananmanickam SS, Datta K, Datta SK (2002) Molecular breeding for the development of blast and bacterial blight resistance in rice cv. IR50. Crop Sci 42:2072-2079. https://doi.org/10.2135/cropsci2002.2072

Nayak P, Basu D, Das S et al (1997) Transgenic elite indica rice plants expressing CryIAc deltaendotoxin of Bacillus thuringiensis are resistant against yellow stem borer (Scirpophaga incertulas). Proc Natl Acad Sci U S A 94(6):2111-2116. https://doi.org/10.1073/pnas.94.6.2111

Norton GJ, Douglas A, Lahner B, Yakubova E, Guerinot ML, Pinson SRM et al (2014) Genome wide association mapping of grain arsenic, copper, molybdenum and zinc in rice (Oryza sativa L.) grown at four international field sites. PLoS One 9:e89685. https://doi.org/10.1371/journal. pone. 0089685

Obara M, Tamura W, Ebitani T, Yano M, Sato T, Yamaya T (2010) Fine-mapping of qRL6.1, a major QTL for root length of rice seedlings grown under a wide range of $\mathrm{NH} 4+$ concentrations in hydroponic conditions. Theor Appl Genet 121:535-547

Ohsumi A, Takai T, Ida M, Yamamoto T, Arai-Sanoh Y, Yano M, Ando T, Kondo M (2011) Evaluation of yield performance in rice near-isogenic lines with increased spikelet number. Field Crops Res 120:68-75. https://doi.org/10.1016/j.fcr.2010.08.013

Ouyang Y, Chen J, Ding J, Zhang Q (2009) Advances in the understanding of inter-subspecific hybrid sterility and wide-compatibility in rice. Chin Sci Bull 54:2332-2341

Paine JA, Shipton CA, Chaggar S et al (2005) Improving the nutritional value of golden rice through increased provitamin A content. Nat Biotechnol 23:482-487

Park S-I, Kim Y-S, Kim J-J, Mok J-E, Kim Y-H, Park H-M, Kim I-S, Yoon H-S (2017) Improved stress tolerance and productivity in transgenic rice plants constitutively expressing the Oryza sativa glutathione synthetase OsGS under paddy field conditions. J Plant Physiol 215:39-47

Pérez L, Soto E, Farré G, Juanos J, Villorbina G, Bassie L, Medina V, Serrato AJ, Sahrawy M, Rojas JA, Romagosa I, Muñoz P, Zhu C, Christou P (2019) CRISPR/Cas9 mutations in the rice Waxy/GBSSI gene induce allele-specific and zygosity-dependent feedback effects on endosperm starch biosynthesis. Plant Cell Rep 38(3):417-433. https://doi.org/10.1007/ s00299-019-02388-z. Epub 2019 Feb 4. PMID: 30715580.

Pinson SRM, Capdevielle FM, Oard JH (2005) Confirming QTLs and finding additional loci conditioning sheath blight resistance in rice using recombinant inbred lines. Crop Sci 45:503-510. https://doi.org/10.2135/cropsci2005.0503

Pradhan S, Chakraborty A, Sikdar N, Chakraborty S, Bhattacharyya J, Mitra J, Manna A, Dutta Gupta S, Sen SK (2016) Marker-free transgenic rice expressing the vegetative insecticidal protein (Vip) of Bacillus thuringiensis shows broad insecticidal properties. Planta 244(4):789-804. https://doi.org/10.1007/s00425-016-2535-1. Epub 2016 May 10

Priyadarshi R, Arremsetty HPS, Singh AK, Khandekar D, Ulaganathan K, Shenoy V (2017) Molecular stacking of wide compatibility gene, $S 5^{n}$ and elongated uppermost internode (eui) gene into IR58025B, an elite maintainer line of rice. J Plant Biochem Biotechnol 26(4):425-435

Ram T, Majumder ND (2007) Introgression of broad-spectrum blast resistance gene(s) into cultivated rice (Oryza sativa ssp. indica) from wild rice O. rufipogon. Curr Sci 92(2):225-230

Rao KV, Rathore KS, Hodges TK, Fu X, Stoger E, Sudhakar D, Williams S, Christou P, Bharathi M, Brown DP, Powell KS, Spence J, Gatehouse AM, Gatehouse JA (1998) Expression of snowdrop lectin (GNA) in transgenic rice plants confers resistance to rice brown planthopper. Plant J 15(4):469-477

Rao SD, Neeraja CN, Madhu Babu P, Nirmala B, Suman K, Rao LVS, Surekha K, Raghu P, Longvah T, Surendra P, Kumar R, Babu VR, Voleti SR (2020) Zinc biofortified rice varieties: challenges, possibilities, and progress in India. Front Nutr 7:26. https://doi.org/10.3389/ fnut. 2020.00026 
Rashid M, Guangyuan H, Guangxiao Y, Hussain J, Xu Y (2012) AP2/ERF transcription factor in rice: genome-wide canvas and syntenic relationships between monocots and eudicots. Evol Bioinformatics Online 8:321-355. https://doi.org/10.4137/EBO.S9369

Reddy O, Siddiq E, Sarma N et al (2000) Genetic analysis of temperature-sensitive male sterility in rice. Theor Appl Genet 100:794-801. https://doi.org/10.1007/s001220051354

Saha P, Majumder P (2006) Transgenic rice expressing Allium sativum leaf lectin with enhanced resistance against sap-sucking insect pests. Planta 223:1329-1343

Sahoo RK, Gill SS, Tuteja N (2012) Pea DNA helicase 45 promotes salinity stress tolerance in IR64 rice with improved yield. Plant Signal Behav 7(8):1042-1046

Saijo Y, Hata S, Kyozuka J, Shimamoto K, Izui K (2000) Overexpression of a single $\mathrm{Ca}^{2+}$ dependent protein kinase confers both cold and salt/drought tolerance on rice plants. Plant J 23:319-327

Sasaki A, Ashikari M, Ueguchi-Tanaka M, Itoh H, Nishimura A, Datta S, Ishiyama K, Saito T, Kobayashi M, Khush GS, Kitano H, Matsuoka M (2002) Green revolution: a mutant gibberellinsynthesis gene in rice. Nature 416(6882):701-702. https://doi.org/10.1038/416701a

Sato Y, Sentoku N, Miura Y, Hirochika H, Kitanoc H, Matsuoka M (1999) Loss-of-function mutations in the rice homeobox gene $\mathrm{OSH} 15$ affect the architecture of internodes resulting in dwarf plants. EMBO J 18(4):992-1002. https://doi.org/10.1093/emboj/18.4.992

Sattari M, Kathiresan A, Gregorio G, Hernandez JE, Nas TM, Virmani SS (2007) Development and use of a two-gene marker-aided selection system for fertility restorer genes in rice. Euphytica $153: 35-42$

Septiningsih EM, Pamplona AM, Sanchez DL, Neeraja CN, Vergara GV, Heuer S, Ismail AM, Mackill DJ (2009) Development of submergence-tolerant rice cultivars: the Sub1 locus and beyond. Ann Bot 103(2):151-160. https://doi.org/10.1093/aob/men206

Shim J, Torollo G, Angeles-Shim RB, Cabunagan RC, Choi I-R, Yeo U-S, Ha W-G (2015) Rice tungro spherical virus resistance into photoperiod-insensitive japonica rice by marker-assisted selection. Breed Sci 65:345-351. https://doi.org/10.1270/jsbbs.65.345

Siddiq EA, Ali J (1999) Innovative male sterility systems for exploitation of hybrid vigour in crop plants: 1. Environment sensitive genetic male sterility system. PINSA B65(6):331-350

Siddiq EA, Singh S (2005) Wide-compatibility system for yield enhancement of tropical rice through intersubspecific hybridization. Adv Agron 87:157-209

Singh SP, Sundaram RM, Biradar SK, Ahmed MI, Viraktamath BC, Siddiq EA (2006) Identification of simple sequence repeat markers for utilizing wide-compatibility genes in inter-subspecific hybrids in rice (Oryza sativa L.). Theor Appl Genet 113:509-517. https://doi.org/10.1007/ s00122-006-0316-0

Singh VK, Singh A, Singh SP, Ellur RK, Choudhary V, Sarkel S, Singh D, Krishnan SG, Nagarajan M, Vinod KK, Singh UD, Rathore R, Prashanthi SK, Agrawal PK, Bhatt JC, Mohapatra T, Prabhu KV, Singh AK (2012) Incorporation of blast resistance into 'PRR78', an elite Basmati rice restorer line, through marker assisted backcross breeding. Field Crops Res 128:8-16

Singla-Pareek SL, Yadav SK, Pareek A, Reddy MK, Sopory SK (2006) Transgenic tobacco overexpressing glyoxalase pathway enzymes grow and set viable seeds in zinc-spiked soils. Plant Physiol 140(2):613-623. https://doi.org/10.1104/pp.105.073734

Song X, Qiu S, Xu C, Li X, Zhang Q (2005) Genetic dissection of embryo sac fertility, pollen fertility, and their contributions to spikelet fertility of intersubspecific hybrids in rice. Theor Appl Genet 110:205-211

Sudhakar T, Panigrahy M, Lakshmanaik M, Babu AP, Reddy CS, Anuradha K, Swamy BPM, Sarla N (2012) Variation and correlation of phenotypic traits contributing to high yield in KMR3: Oryza rufipogon introgression lines. Int J Plant Breed Genet 6:69-82

Sun YW, Jiao GA, Liu ZP, Zhang X, Li JY, Guo XP, Du WM, Du JL, Francis F, Zhao YD, Xia LQ (2017) Generation of high-amylose rice through CRISPR/Cas9-mediated targeted mutagenesis of starch branching enzymes. Front Plant Sci 8:298. https://doi.org/10.3389/fpls.2017.00298 
Sundaram RM, Vishnupriya MR, Biradar SK, Laha GS, Reddy AG, Rani NS, Sarma NP, Sonti RV (2008) Marker assisted introgression of bacterial blight resistance in Samba Mahsuri, an elite indica rice variety. Euphytica 160(3):411-422

Swamy BPM, Kumar A (2013) Genomics-based precision breeding approaches to improve drought tolerance in rice. Biotechnol Adv 31(8):1308-1318. https://doi.org/10.1016/j. biotechadv.2013.05.004

Swamy BPM, Sarla N (2008) Yield-enhancing quantitative trait loci (QTLs) from wild species. Biotechnol Adv 26(1):106-120

Swamy BPM, Kaladhar K, Ramesha MS, Viraktamath BC, Sarla N (2011) Molecular mapping of QTLs for yield and yield-related traits in Oryza sativa cv. Swarna $\times$ O. nivara (IRGC81848) backcross population. Rice Sci 18(3):178-186

Swamy BPM, Kaladhar K, Shobharani N, Prasad GSV, Viraktamath BC, Reddy GA, Sarla N (2012) QTL analysis for grain quality traits in $2 \mathrm{BC}_{2} \mathrm{~F}_{2}$ populations derived from crosses between Oryza sativa cv. Swarna and 2 accessions of $O$. nivara. J Hered 103(3):442-452

Swamy BPM, Kaladhar K, Reddy GA, Viraktamath BC, Sarla N (2014) Mapping and introgression of QTL for yield and related traits in two backcross populations derived from Oryza sativa cv. Swarna and two accessions of O. nivara. J Genet 93(3):643-654

Swamy BPM, Descalsota GIL, Nha CT, Amparado A, Inabangan-Asilo MA, Manito C, Tesoro F, Reinke R (2018) Identification of genomic regions associated with agronomic and biofortification traits in DH populations of rice. PLoS One 13(8):e0201756

Ueguchi-Tanaka M, Fujisawa Y, Kobayashi M, Ashikari M, Iwaski Y, Kitano H, Matsuoka M (2000) Rice dwarf mutant $d l$, which is defective in the alpha subunit of the heterotrimeric G protein, affects gibberellin signal transduction. Proc Natl Acad Sci U S A 97(21):11638-11643. https://doi.org/10.1073/pnas.97.21.11638

Uga Y, Sugimoto K, Ogawa S et al (2013) Control of root system architecture by DEEPER ROOTING 1 increases rice yield under drought conditions. Nat Genet 45:1097-1102

Valarmathi P, Kumar G, Robin S, Manonmani S, Dasgupta I, Rabindran R (2016) Evaluation of virus resistance and agronomic performance of rice cultivar ASD 16 after transfer of transgene against Rice tungro bacilliform virus by backcross breeding. Virus Genes 52(4):521-529. https://doi.org/10.1007/s11262-016-1318-x. Epub 2016 Mar 16

Wang F, Wang C (2016) Enhanced rice blast resistance by CRISPR/Cas9-targeted mutagenesis of the ERF transcription factor gene OsERF922. PLoS One 11(4):1-18

Wang Y, Pinson SRM, Fjellstrom RG, Tabien RE (2012a) Phenotypic gain from introgression of two QTL, $q S B$ 9-2 and $q S B 12-1$ for rice sheath blight resistance. Mol Breed 30:293-303

Wang P, Xing Y, Li Z et al (2012b) Improving rice yield and quality by QTL pyramiding. Mol Breed 29:903-913. https://doi.org/10.1007/s11032-011-9679-2

Wang L, Lu Q, Wen X, Lu C (2015) Enhanced sucrose loading improves rice yield by increasing grain size. Plant Physiol 169:2848-2862

Wang S, Tholen D, Zhu X-G (2017a) C4 photosynthesis in C3 rice: a theoretical analysis of biochemical and anatomical factors. Plant Cell Environ 40:80-94

Wang Y, Jiang W, Liu H, Zeng Y, Du B, Zhu L, He G, Chen R (2017b) Marker assisted pyramiding of Bph6 and Bph9 into elite restorer line 93-11 and development of functional marker for Bph9. Rice (N Y) 10(1):51. https://doi.org/10.1186/s12284-017-0194-x

Wei F-J, Droc G, Guiderdoni E, Hsing YC (2013) International consortium of rice mutagenesis: resources and beyond. Rice (N Y) 6(1):39

Xiao J, Grandillo S, Ahn SN, McCouch SR, Tanksley SD, Li J, Yuan L (1996) Genes from wild rice improve yield. Nature 384:223-224

Xu K, Xia X, Fukao T, Canlas P, Maghirang-Rodriguez R, Heuer S et al (2006) SublA is an ethylene response factor-like gene that confers submergence tolerance to rice. Nature 442:705-708

Xu R, Li H, Qin R, Wang L, Li L, Wei P et al (2014) Gene targeting using the Agrobacterium tumefaciens mediated CRISPR-Cas system in rice. Rice 7:5. https://doi.org/10.1186/ s12284-014-0005-6 
Xu R, Qin R, Li H, Li D, Li L, Wei P et al (2017) Generation of targeted mutant rice using a CRISPR-Cpf1 system. Plant Biotechnol J 15:713-717. https://doi.org/10.1111/pbi.12669

Yadav S, Anuradha G, Kumar RR, Vemireddy LR, Sudhakar R, Donempudi K, Venkata D, Jabeen F, Narasimhan YK, Marathi B, Siddiq EA (2015) Identification of QTLs and possible candidate genes conferring sheath blight resistance in rice (Oryza sativa L.). Springerplus 4:175

Yamamuro C, Ihara Y, Wu X, Noguchi T, Fujioka S, Takatsuto S, Ashikari M, Kitano H, Matsuoka M (2000) Loss of function of a rice brassinosteroid insensitive1 homolog prevents internode elongation and bending of the lamina joint. Plant Cell 12(9):1591-1606

Yanagihara $S$ et al (1995) Molecular analysis of the inheritance of the $S-5$ locus, conferring wide compatibility in indica/japonica hybrids of rice (Oryza sativa L.). Theor Appl Genet 90:182-188

Ye X, Al-Babili S, Klöti A, Zhang J, Lucca P, Beyer P, Potrykus I (2000) Engineering the provitamin A ( $\beta$-carotene) biosynthetic pathway into (carotenoid free) rice endosperm. Science 287:303-305

Yi M, Nwe KT, Vanavichit A, Chaiarree W, Toojinda T (2009) Marker assisted backcross breeding to improve cooking quality traits in Myanmar rice cultivar Manawthukha. Field Crops Res 113:178-186

Yin X, Biswal AK, Dionora J, Perdigon KM, Balahadia CP, Mazumdar S, Chater C, Lin HC, Coe RA, Kretzschmar T, Gray JE, Quick PW, Bandyopadhyay A. (2017) CRISPR-Cas9 and CRISPR-Cpf1 mediated targeting of a stomatal developmental gene EPFL9 in rice. Plant Cell Rep. 36(5):745-757. https://doi.org/10.1007/s00299-017-2118-z.

Yuan LP, Fu XQ (1995) Technology of hybrid rice production. FAO, Rome

Zhang J, Li X, Jiang G, Xu Y, He Y (2006) Pyramiding of Xa7 and Xa21 for the improvement of disease resistance to bacterial blight in hybrid rice. Plant Breed 125:600-605. https://doi. org/10.1111/j.1439-0523.2006.01281.x

Zhang F, Jiang Y-Z, Yu S-B, Ali J, Paterson AH, Khush GS, Xu J-L, Gao Y-M, Fu B-Y, Lafitte R, Li Z-K (2013) Three genetic systems controlling growth, development and productivity of rice (Oryza sativa L.): a reevaluation of the 'Green Revolution'. Theor Appl Genet 126:1011-1024

Zhou H, He M, Li J, Chen L, Huang Z, Zheng S, Zhu L, Ni E, Jiang D, Zhao B, Zhuang C (2016) Development of commercial thermo-sensitive genic male sterile rice accelerates hybrid rice breeding using the CRISPR/Cas9-mediated TMS5 editing system. Sci Rep 6:37395. https:// doi.org/10.1038/srep37395

Zuo SM, Yin YJ, Zhang L, Zhang YF, Chen ZX, Pan XB (2007) Breeding value and further mapping of a QTL $q S B-11$ conferring the rice sheath blight resistance. Chin J Rice Sci 21(2):136-142

Zuo M, Zhu YJ, Yin YJ, Wang H, Zhang YF, Chen ZX, Gu SL, Pan XB (2014) Comparison and confirmation of quantitative trait loci conferring partial resistance to rice sheath blight on chromosome 9. Plant Dis 98(7):957-964

Open Access This chapter is licensed under the terms of the Creative Commons Attribution 4.0 International License (http://creativecommons.org/licenses/by/4.0/), which permits use, sharing, adaptation, distribution and reproduction in any medium or format, as long as you give appropriate credit to the original author(s) and the source, provide a link to the Creative Commons license and indicate if changes were made.

The images or other third party material in this chapter are included in the chapter's Creative Commons license, unless indicated otherwise in a credit line to the material. If material is not included in the chapter's Creative Commons license and your intended use is not permitted by statutory regulation or exceeds the permitted use, you will need to obtain permission directly from the copyright holder.

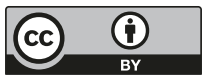

